\title{
Review
}

\section{Molecular Mechanisms of Canine Osteosarcoma Metastasis}

\author{
Sylwia S. Wilk and Katarzyna A. Zabielska-Koczywąs *
}

Department of Small Animal Diseases and Clinic, Institute of Veterinary Medicine, Warsaw University of Life Sciences, Nowoursynowska 159c, 02-776 Warsaw, Poland; sylwia_wilk@sggw.edu.pl

* Correspondence: katarzyna_zabielska@sggw.edu.pl; Tel.: +48-225936136

Citation: Wilk, S.S.;

Zabielska-Koczywas, K.A. Molecular Mechanisms of Canine Osteosarcoma Metastasis. Int. J. Mol. Sci. 2021, 22, 3639. https://doi.org/10.3390/ ijms22073639

Academic Editor: Sabrina Strano

Received: 1 February 2021

Accepted: 26 March 2021

Published: 31 March 2021

Publisher's Note: MDPI stays neutral with regard to jurisdictional claims in published maps and institutional affiliations.

Copyright: (c) 2021 by the authors. Licensee MDPI, Basel, Switzerland. This article is an open access article distributed under the terms and conditions of the Creative Commons Attribution (CC BY) license (https:// creativecommons.org/licenses/by/ $4.0 /)$.

\begin{abstract}
Osteosarcoma (OSA) represents the most common bone tumor in dogs. The malignancy is highly aggressive, and most of the dogs die due to metastasis, especially to the lungs. The metastatic process is complex and consists of several main steps. Assessment of the molecular mechanisms of metastasis requires in vitro and especially in vivo studies for a full evaluation of the process. The molecular and biological resemblance of canine OSA to its human counterpart enables the utilization of dogs as a spontaneous model of this disease in humans. The aim of the present review article is to summarize the knowledge of genes and proteins, including $p 63$, signal transducer and activator of transcription 3 (STAT3), Snail2, ezrin, phosphorylated ezrin-radixin-moesin (p-ERM), hepatocyte growth factor-scatter factor (HGF-SF), epidermal growth factor receptor (EGFR), miR-9, and miR$34 \mathrm{a}$, that are proven, by in vitro and/or in vivo studies, to be potentially involved in the metastatic cascade of canine OSA. The determination of molecular targets of metastatic disease may enhance the development of new therapeutic strategies.
\end{abstract}

Keywords: canine OSA; metastasis; molecular mechanisms; cell lines; in vitro; in vivo; animal models

\section{Introduction}

Osteosarcoma (OSA) is the most common bone malignancy that occurs in dogs, accounting for $80-98 \%$ of malignant bone tumors [1,2], with an incidence rate estimated to be between at least 5.6 and 13.8/10,000 [3-5]. However, it should be pointed out that there is limited data on the statistics on OSA incidence in dogs, as there is no consistent method for reporting cancer in dogs, and the presented estimation is based on data from the 1990s. The origin of neoplasia includes osteoblastic cells producing osteoid or malignant mesenchymal cells. Prevalence is significantly higher in older dogs, with a mean age of 8 years, from large and giant breeds, and in most cases affects the appendicular skeleton (64\% of patients) [1,6]. The common locations of this malignancy are the proximal humerus and distal radius (Figure 1A) or the distal femur and proximal tibia (Figure 1B). OSA demonstrates aggressiveness and a propensity to metastasize, most frequently to the lungs [1-3] (Figure 1C). Other sites of metastatic disease include the bones and soft tissue of internal organs, such as the liver, spleen, or lymph nodes [2]. It is estimated that at the moment of diagnosis, $80-90 \%$ of dogs have micrometastases in their lungs [7]. Despite surgical and chemotherapeutic treatment, less than $20 \%$ of dogs survive more than 2 years from diagnosis, probably due to metastatic disease [8].

OSA cells metastasize by hematogenous spread [9]. The process of metastasis is complex and involves several main steps: 1 . neo-vascularization within the primary tumor, 2. local invasion and subsequent intravasation, 3. transportation and obstruction at vessels of the secondary site, 4 . extravasation and migration, and 5 . outgrowth at the secondary site [10] (Figure 2).

Understanding the molecular mechanisms driving metastasis, differences in tumor cells colonizing distant organs from those of primary tumor cells, and recognizing potential molecular targets are important steps in the effective development of anti-metastatic drugs [11]. Both in vitro and in vivo studies are needed to fully evaluate the molecular 
mechanisms of candidate compounds [12,13]. The in vitro tests can be utilized to assess the invasive phenotype (transwell invasion assay) of canine OSA cells as well as their ability to migrate (wound healing assay (WHA)), which are the main steps of the metastatic cascade. The controlled environment of in vitro studies enables varying expressions of selected factors, which cannot be achieved in vivo [14]. Nevertheless, only in vivo modelling facilitates the mimicking of natural tumor cell behavior and its interactions with the local and systemic environments of a living organism, both crucial for anti-metastatic drug development [15]. Within in vitro cultures, tumor cells lose specific interactions corresponding to tissue formation, which may affect the expression of particular targets [14]. The perfect in vivo model to study preclinical metastasis should produce metastases within a few months, be immunocompetent with the tumor specimen, and be orthotopic [11]. The most widely used in vivo metastatic frameworks are immune-competent mice (engrafted with murine tumors) or immunosuppressed mice (xenografts) $[15,16]$. Moreover, the primary canine or human OSA tumor implantation into the side of an orthotopic mouse model exemplifies all of the metastatic cascade steps [16]. Other hosts occasionally used in metastatic research include zebrafish, Drosophila, and chick embryo chorioallantoic membrane (CAM) [11]. The CAM has been shown to be a reliable model to study neoplastic cell extravasation - an important step of the metastatic cascade [17]. Furthermore, Kim and collaborators demonstrated [17] the potential utility of this model in the development of novel anti-metastatic strategies that specifically target neoplastic cell extravasation.

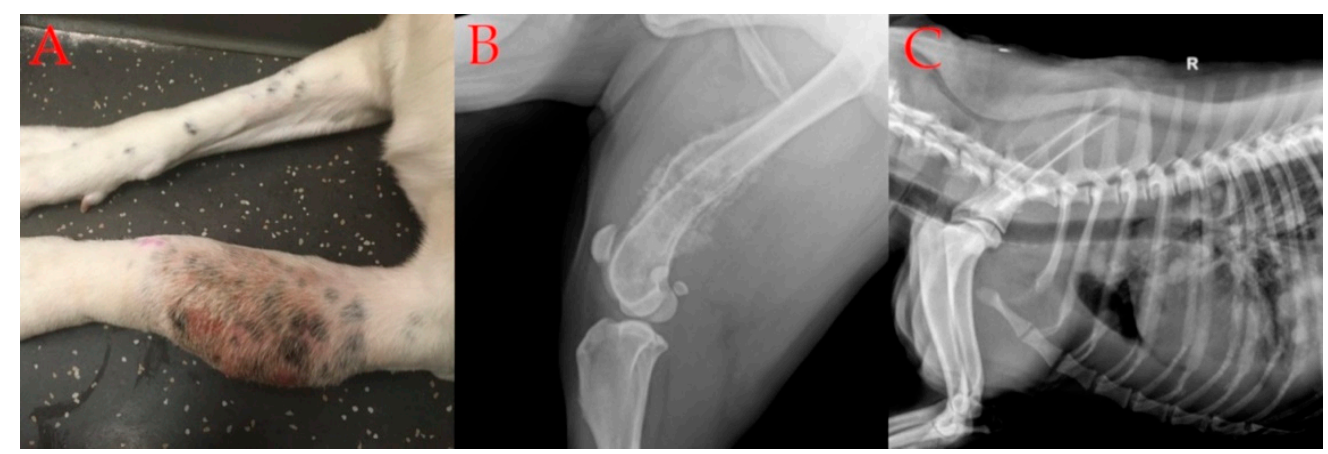

Figure 1. (A): Clinical appearance of an 11-month mixed breed dog with osteosarcoma; (B): X-ray of the primary canine osteosarcoma localized in the distal femur; (C): X-ray of lung metastases in canine osteosarcoma.

Spontaneous in vivo models of neoplastic disease are animals that develop the malignancy in a natural manner. Companion animals exhibit resemblances in the pathological characteristics of a specific cancer to its human counterpart, including high incidence rates and response to the therapy, and may be used as a spontaneous in vivo neoplastic model [18]. In vivo tests using a spontaneous canine model of the disease enable evaluation of the potential value of selected targets in pathogenesis and prognosis, especially the evaluation of their expression within the parameters of median survival time (ST) and median disease-free interval (DFI) $[7,19,20]$. X-ray is a standard technique to detect macrometastases in dogs (Figure 1C). Monitoring macrometastasis in preclinical models is performed with non-invasive imaging methods, such as computed tomography (CT), magnetic resonance imaging (MRI), or bioluminescence [11]. Micrometastases are predicted to be present at the time of the primary tumor diagnosis but are not evident using conventional imaging techniques [11]. Both in preclinical and spontaneous in vivo models, micrometastases can be detected by histological analysis. Substitute or additional methods, such as immunohistochemistry (IHC), flow cytometry of bone marrow aspirates, and molecular assays for tumor-derived DNA in blood samples, have questionable predictive power [11]. 


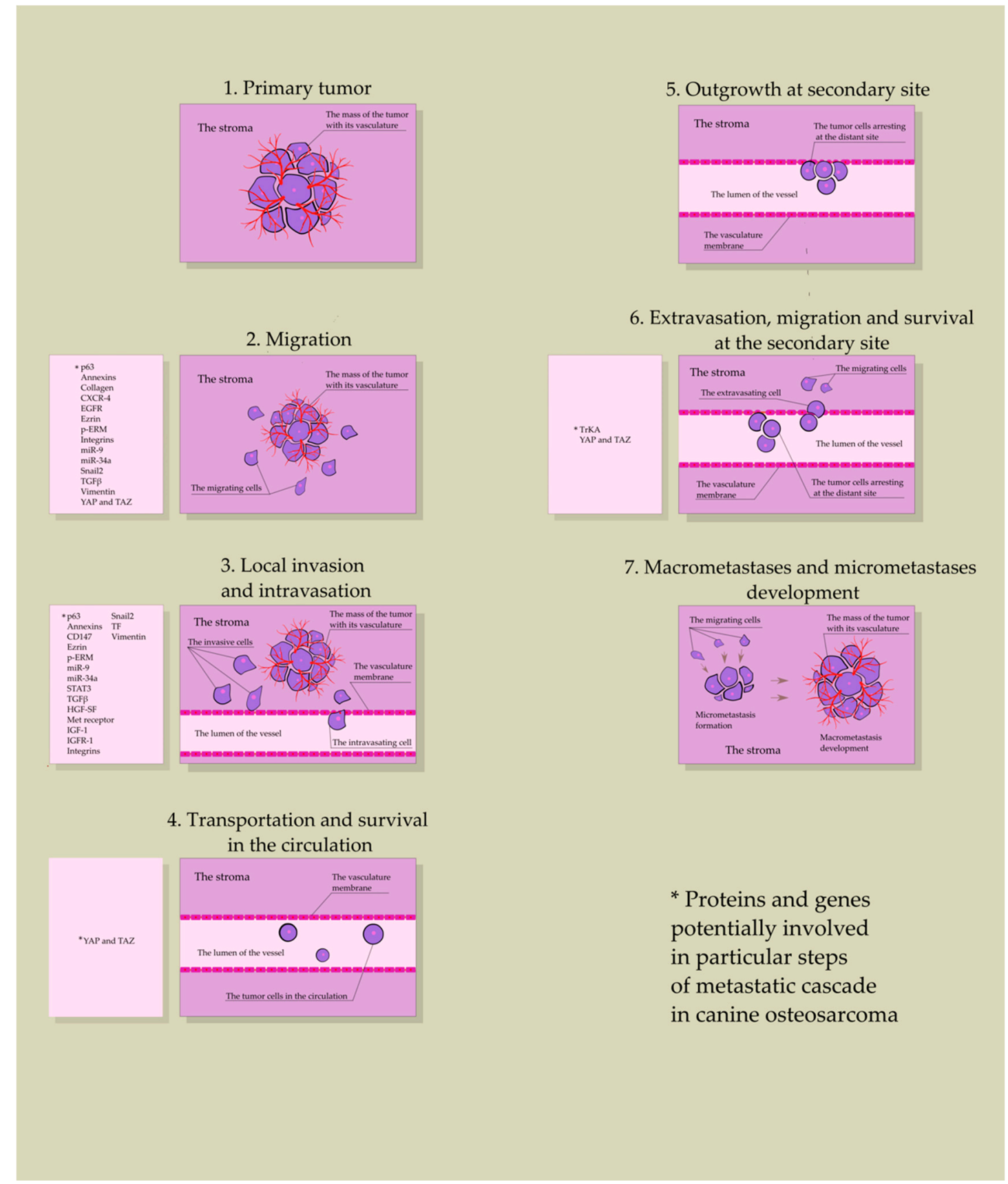

Figure 2. Steps of the metastatic cascade in canine osteosarcoma, including genes and proteins potentially involved in each step.

The aim of the present review is to summarize the actual knowledge of proteins, genes, and nucleic acids implicated in the process of canine OSA metastasis, such as $p 63$, signal transducer and activator of transcription 3 (STAT3), Snail2, ezrin, phosphorylated ezrinradixin-moesin (p-ERM), hepatocyte growth factor-scatter factor (HGF-SF), epidermal growth factor receptor (EGFR), and miR-9 and miR-34a (Figure 2), as they may act as biomarkers or play an important role in targeted drug delivery. Moreover, a determination of their functions in canine OSA requires investigation due to the biological and molecular resemblance of this tumor to its human counterpart. Canine OSA remains an in vivo model of the human malignancy, utilized in preclinical tests of novel treatment methods [20,21].

\section{Search Methodology}

This review was based on a search of the PubMed database (http:/ / www.ncbi.nlm. nih.gov/pubmed, accessed on 19 February 2021) using the terms "canine" OR "dogs" 
AND "osteosarcoma" AND "cell line" AND "metastasis". Out of 62 articles that meet the criteria, only original articles that included information on canine osteosarcoma metastasis at a molecular level were selected. This review is a synthesis of current knowledge in the field and highlights the genes and proteins involved in molecular mechanisms of canine osteosarcoma metastasis that, based on promising results of in vitro and/or in vivo studies, need further investigation. To fully cover a topic, the review also provides the information from other selected canine OSA articles (used in the introduction section) and particular proteins and genes to enhance the knowledge on their biological role.

\section{Proteins and Genes Potentially Involved in Canine OSA Metastasis-In Vitro and In Vivo Studies}

\section{1. $p 63$}

$p 63$ is a transcription factor that belongs to the $p 53$ family. $p 63$ encodes protein isoforms using two promoters: TAp63 and $\Delta$ p63 [22]. Expression of the $\Delta$ p63 isoform is often aberrant in several types of human neoplasias, and its upregulation is related to a poor prognosis [22]. Cam et al. [23] demonstrated an overexpression of $\Delta p 63$ in canine OSA cell lines and primary OSA tumors in comparison to normal canine osteoblasts. In the same study, overexpression of $\Delta$ p63 enhanced the number of invading D17 cells and improved their ability to migrate in a WHA. It was indicated that D17 cells overexpressing $\Delta$ p63 exhibit increased phosphorylation of STAT3 and secretion of vascular endothelial growth factor A (VEGF-A), in comparison to control D17 cells. The data suggest that the role of $\Delta$ p63 in cellular invasion and migration is presumably associated with activating STAT3, interleukin 8 (IL-8), and VEGF-A production [23].

The investigators performed further studies with severe combined immunodeficient (SCID) mice intravenously xenografted with canine OSA cells, which revealed that the expression of $\triangle \mathrm{Np} 63$ correlates with the metastatic potential of OSA cells and is higher (three-fold more metastases, $p<0.05$ ) in the OSA16 cell line when compared to the D17 cell line. In the same study, the correlation between $\Delta \mathrm{Np} 63$ expression and metastasis was further confirmed by demonstrating an increased lung colonization of D17 cells overexpressing $\triangle \mathrm{Np} 63$ after IV inoculation in SCID mice, in comparison to control D17 cells. The in vivo experiment data may highlight the involvement of $\Delta \mathrm{Np} 63$ in the metastatic process of canine OSA. The authors suggest its role in mediating the expression of cytokines, such as IL-8, interleukin-11 (IL-11), and oncostatin M (OSM), but the exact molecular mechanism of $\Delta \mathrm{Np} 63$ activity in metastasis remains unclear and requires further investigation [23]. Nevertheless, the results of both in vitro and in vivo studies clearly indicate that $\Delta \mathrm{Np} 63$ is a potential target for novel anti-metastatic therapies for canine OSA.

\subsection{STAT3}

STAT3 is a protein from the family of transcription factors that plays a role in the development, progression, and process of metastasis in some types of neoplasias, including tumors of mesenchymal origin [24]. Activated STAT3 is associated with poor prognosis in some human malignancies, including lymphomas, blood, and solid tumors [25]. Fossey et al. [21] established the activation of STAT3 in numerous canine OSA tumors and canine cell lines. In the same study, the investigators demonstrated that the inhibition of STAT3 with the small-molecule Src inhibitor SU6656 or direct downregulation (by using the smallmolecule inhibitor LL3 or siRNA to modulate STAT3 expression) showed a noticeable reduction of mRNAs encoding matrix metalloproteinase 2 (MMP-2) and vascular endothelial growth factor (VEGF), and led to downregulation of the proenzyme and active form of MMP-2 and decreased expression of the VEGF protein. The data suggest that STAT3 activity impacts metastasis and cell invasion through the expression of crucial proteins involved in these processes [21]. 


\subsection{Snail2}

Various in vitro studies (using the CAM assay and IHC of canine OSA tumors) assessed the role of Snail2, a zinc finger protein and transcription factor from the Snail family, in canine OSA metastasis. Snail2 decreases the expression of E-cadherin, enabling the cells to break cell-cell connections [26]. Immunohistochemical analysis on archived canine OSA showed a significantly higher expression of Snail2 in high-grade canine OSA tumors $(\mathrm{n}=11)$ in comparison to intermediate-grade $(\mathrm{n}=5)$ and low-grade $(\mathrm{n}=4)$ samples [27]. Furthermore, the expression of Snail2 in material derived from appendicular bone tumors was significantly higher than skull-derived OSA [27]. As it is well known that appendicular long bone OSA in dogs metastasizes in $80-90 \%$ of cases [1], while skull OSA metastases occur less frequently, according to Sharili et al. [27], this fact may suggest that Snail2 could play a role in the process of cell migration. It should be considered that the study was performed on small numbers of dogs, and archived material was used for IHC, which may limit the results. Downregulation of Snail2 by small interfering RNA demonstrated decreased motility of D17 cells using the scratch assay, suggesting that Snail2 is required for migration [28]. However, overexpression of Snail2 using a Snail2 plasmid with a CMV promoter did not increase the motility of D17 cells. This could be due to the fact that D17 cells metastasize to the lungs and their migration rate cannot be enhanced by increasing Snail2 activity, as they may already be migrating at their highest rate [28]. It was shown that the downregulation of Snail2 can disorganize cytoskeleton architecture without impacting focal adhesions, and D17 cells with increased Snail2 expression exhibited normal cytoskeleton organization and more focal adhesions [27]. This suggests that Snail2 can regulate cell adhesion and cytoskeleton action in OSA, which can be associated with promoting cell migration and metastasis [28]. Further studies on the CAM model demonstrated that the ability to invade the stroma and intravasation of Snail2 knockdown D17 cells was significantly reduced in comparison to control (D17) cells. Results obtained indicated that selectively blocking Snail2 may reduce metastasis in patients with OSA [28]. In various human cancer cells (e.g., lung adenocarcinoma and squamous cell carcinoma), the function of Snail2 in the metastatic processes is considered to be associated with the promotion of MMP expression, but the exact mechanism remains unknown [29,30]. MMPs are proteolytic, calcium-dependent, and zinc-containing enzymes from the metzincin superfamily that degrade and remodel the extracellular matrix [31]. In human medicine, MMP inhibitors were developed as antimetastatic agents. While they inhibited the tissue invasion of neoplastic cells in the metastatic cascade, they failed to show strong efficacy in phase II and III clinical trials [11]. In veterinary medicine, Lana et al. [32] detected significantly higher $(p<0.001)$ MMP-2 (gelatinase A) and MMP-9 (gelatinase B) expression in 30 high-grade OSA samples relative to nearby stromal control tissue. Loukopoulos et al. [33] demonstrated that the synthesis of pro-MMP-9 in canine OSA positively correlates with the histologic grade of the malignancy [34]. In further investigations, Loukopoulos et al. [33] established a noticeable expression of MMP-2 and MMP-9 in three newly derived canine OSA cell lines. Unfortunately, we found no studies of MMP expression in metastatic cell lines nor metastasis in canine patients with OSA despite clear evidence of correlation between MMP-2 and MMP-9 with tumor malignancy. As a result, it cannot be clearly stated whether MMPs play an important role in the metastatic cascade of canine OSA, and further molecular and in vivo studies are needed.

\subsection{Vimentin}

Vimentin is a structural protein expressed in cells of mesenchymal origin and accounts for the main constituent of their cytoskeleton. Physiologically, it is involved in sustaining structural integrity, flexibility, the shape of cells, as well as the processes of migration and adhesion $[35,36]$. In neoplasias of epithelial origin, vimentin serves as a biomarker of the epithelial-to-mesenchymal transition (EMT) [37]. During the EMT process, epithelial cells acquire the ability to migrate and invade, which is crucial to initiate the metastatic cascade [38,39]. Despite OSA's mesenchymal origin, human OSA cells are capable of 
undergoing EMT, leading to increased motility and invasiveness [40]. Overexpression of vimentin in canine OSA is suspected to be associated with increased tumor cell motility, invasiveness, and a more aggressive phenotype [41]. Roy et al. [35] noticed a higher (over 3-fold) expression of vimentin in the canine OSA metastatic cell line HMPOS versus the nonmetastatic cell line POS. A similar association was observed in their human counterparts, where expression of vimentin was higher in the metastatic $143 \mathrm{~B}$ cell line versus the nonmetastatic HOS cell line, although the increase was only 1.2-fold higher [35].

\subsection{Growth Factors and Their Specific Receptors}

The implication of growth factors in promoting the invasive phenotype of neoplastic cells has been described in various human and canine malignancies, including OSA [42,43].

\subsubsection{Vascular Endothelial Growth Factor (VEGF)}

Plasma VEGF is a homodimer signal protein and a member of the platelet-derived growth factor family. Physiologically, VEGF is a mitogen for cells of endothelial origin and promotes angiogenesis [44,45]. Expression of this protein in primary tumors is associated with poor prognosis and high rates of metastasis in some types of human malignancies, including carcinomas of the gastrointestinal tract, hepatocellular carcinoma, and OSA [46-48]. In human OSA tumors, the VEGFA level was positively correlated with the presence of lung metastasis [48]. In vitro studies performed by Cam et al. [23] determined that $\Delta \mathrm{Np} 63$ contributes to the production of VEGF in canine OSA through effects on STAT3 and IL-8. Depletion of $\triangle \mathrm{Np} 63$ in canine OSA cells resulted in a decreased level of VEGF and a noticeable reduction of endothelial tube formation in transwell endothelial tube formation assays. These findings suggest that VEGF may be involved in the metastatic cascade of canine OSA by promoting the process of angiogenesis [23].

\subsubsection{Insulin Growth Factor 1 (IGF-1) and Its Receptor}

IGF-1, which plays a part in promoting the metabolic and growth effects of cells, is a polypeptide structurally homological to proinsulin [49]. Regulating the process of osteoblast proliferation, IGFs are one of the most significant growth factors in human bone tissue. In culture, both human osteoblasts and OSA cells have receptors for IGF-1 and are able to proliferate in response to IGF-1 [42]. In veterinary medicine, treating cells with IGF-1 was shown to increase invasiveness in just one of three osteosarcoma cell lines (with high insulin-like growth factor receptor 1 (IGF1-R) expression) [42]. This suggests a cell line-dependent role of IGF-1 in canine OSA invasive phenotypes. Furthermore, the investigators performed studies on immunodeficient mice indicating that aggressive in vivo behavior (tumorigenesis and occurrence of metastasis) of canine osteosarcoma cells positively correlates with the expression of IGF1-R [42]. However, the study was conducted on only three mice per group, which reduced the power of the study and may be unrepresentative of the population. Data regarding IGF1-R in canine OSA is limited to one study where immunostaining was performed and showed a shorter survival time in canine appendicular OSA patients with high IGF1-R immunoexpression compared to those with low IGF1-R [19]. Unfortunately, this study lacked further information on the role of IGF-1 and IGF1-R in the metastatic cascade.

\subsubsection{Transforming Growth Factor Beta (TGF $\beta$ )}

TGF $\beta$ is a secreted cytokine that exists in isoforms: TGF $\beta$ 1, 2, and 3 [50]. All of the isoforms regulate the differentiation of mesenchymal stem cells, which affects the skeletal development of embryos. Postnatally, TGF $\beta$ plays a part in bone homeostasis, including differentiation, proliferation, the survival of osteoblasts, as well as the motility of their precursors [51]. Activity of TGF $\beta$ is mediated by two different pathways: the canonical (Smad dependent) and non-canonical (Smad independent) [50]. In human and canine OSA, the factor is implicated in the growth, migration, and invasion of tumor cells $[52,53]$. The expression of transforming growth factor beta receptors (TGF $\beta R I$ and 
TGF $\beta$ RII) in both normal osteoblasts and five malignant canine OSA cell lines indicated that the TGF $\beta$ signaling pathway is not characteristic of the malignant phenotype but is active in reparative osteoblasts [53]. The authors used a WHA to assess an alteration in canine OSA cell motility after blocking a Smad-dependent TGF $\beta$-mediated pathway (through treatment with LY2109761, a small-molecule inhibitor of TGFßRI and TGFßRII). Decreased migration was evaluated as cell line dependent, with the greatest reduction in the D17 cell line, moderate in the HMPOS cell line, and minimally altered in the Abrams cell line. Complete blocking of both canonical and non-canonical signaling did not result in diametrical inhibition of cell motility [53].

\subsubsection{HGF-SF and Its Receptor (Met Receptor)}

HGF-SF is a heterodimer that consists of two subunits: $\alpha$ and $\beta$ [54]. The factor is produced by cells of mesodermal origin, and for the most part impacts the biological functions of epithelial and endothelial cells [55]. HGF-SF is a mitogen for certain cell types, such as hepatocytes, keratinocytes, or kidney epithelium [54]; it also stimulates cell motility [56]. The cell surface receptor for this growth factor is the c-Met tyrosine kinase receptor, encoded by c-MET [54]. Normal osteoblasts and osteoclasts express c-Met, but secretion of HGF-SF occurs only in osteoclasts. The factor is an inducer of proliferation in both osteoblasts and osteoclasts, and in osteoclasts, it affects cell motility [57]. Upregulation of c-Met was described in human and canine OSA [58-60]. The expression of c-Met can be associated with the metastatic phenotype of human OSA [61]. High expression of c-Met mRNA was demonstrated with Northern Blot and real-time PCR (RT-PCR) analysis of both canine OSA cell lines [57] and five of seven canine OSA biopsies [58]. Met-inhibiting molecules (met-specific interfering RNA and small-molecule inhibitor of Met catalytic activity PHA-665752) reduced the invasiveness of canine OSA cells [60]. The data suggest a contribution of HGF and the Met receptor on the metastatic phenotype of canine osteosarcoma $[58,60]$.

\subsubsection{EGFR (ErbB1, HER1)}

EGFR belongs to the family of ErbB receptor proteins, containing four members: ErbB1, ErbB2, ErbB3, and ErbB4 [43]. This transmembrane receptor consists of two domains: extracellular, which is the ligand binding domain, and cytoplasmic, which encodes the EGF-regulated tyrosine kinase [61]. The major role of tyrosine kinase is to regulate cell proliferation [62]. In tumor development, deregulation of EGFR signaling results in the enhancement of cell proliferation, motility, and angiogenesis, as well as a decrease in apoptosis [63]. In human OSA, high expression of EGFR is associated with the occurrence of distant metastases and poor outcomes [64]. A noticeably higher expression of EGFR was determined in primary and metastatic canine OSA tumors compared to normal bone tissue specimens, as well as in several canine OSA cell lines [43]. Furthermore, the expression of EGFR was significantly higher in canine primary OSA metastases to the lungs, in comparison to extrapulmonary OSA metastases. The results indicate a potential role of EGFR in promoting an aggressive phenotype in canine OSA, although a potential molecular mechanism remains undescribed [43].

\subsection{Integrins}

Integrins are a family of glycoprotein receptors, heterodimers consisting of two subunits: alpha and beta. Their biological function is to regulate many cellular processes, including cell adhesion, migration, and metastasis [65]. Integrins play a part in the invasiveness of tumor cells by activating MMPs and consequently inducing a disintegration of the extracellular matrix (ECM) [66]. In human medicine, high expression of $\beta 1$ integrin was shown for OSA metastatic cell lines; it was not identified in two canine OSA cell lines (non-metastatic POS and artificially generated metastatic-HMPOS [35]). However, a strong limitation of the study was that it was performed only on two OSA cell lines: POS, derived from a primary spontaneous canine femoral OSA, and the HMPOS, which was derived 
from POS after serial implantation into the lungs of nude mice [67]. In veterinary medicine, RT-PCR analyses revealed that $\beta 4$ integrin seems to be associated with an invasive phenotype of canine OSA cell lines. Additionally, inducing $\beta 4$ integrin genes in non-invasive canine OSA cells led to their acquirement of an invasive phenotype [68]. However, further in vitro and in vivo studies should be performed to confirm the role of $\beta 4$ integrins in the metastatic cascade.

\section{7. $C D 147$}

CD147 (basigin; EMMPRIN-extracellular MMP inducer; cluster of differentiation CD147) is a plasma membrane protein of the immunoglobulin superfamily, with variable expression in a number of cell types, such as leukocytes, hematopoietic, endothelial, and epithelial cells [69]. Physiologically, it is involved in the regulation of biological processes, such as spermatogenesis [70], lymphocyte responsiveness [71], and MMP synthesis [69]. The expression of CD147 is also described in tumors, including human and canine OSA [35,72]. Stimulating the production of MMPs in neoplasias, CD147 implicates tumor invasiveness and the promotion of metastasis [72,73]. Roy et al. [35] established a 2.12-fold change in CD147 expression in HMPOS (artificially derived metastatic cell line) versus POS (non-metastatic cell line) and further confirmed it by western blot (WB), flow cytometry, and IHC of cell pellets. Similar results were obtained for canine patient samples (although examining only two distinct sets-with five sections of each-from paired primary tumor and lung metastasis samples), although the intensity of CD147 in IHC was not as intense as that in cell lines. The obtained results suggest that CD147 may potentially be considered as a metastatic biomarker and therapeutic target in canine OSA [35]. However, further studies of more cell lines (especially primary metastatic cell lines) and many more canine samples from both primary and metastatic OSA are obligatory to confirm this hypothesis.

\subsection{Collagen}

Collagen is the major structural protein component of the extracellular matrix of connective tissues [74]. It is suggested that enhanced collagen density may initiate a promotion of tumorigenesis, invasion, and metastasis in human breast carcinoma [75]. In human OSA, intercommunication between tumor cells and type I collagen mediates MMP-2 synthesis and activation [76]. Forty-six percent higher expression of collagen was demonstrated in the metastatic canine OSA cell line HMPOS versus the non-metastatic cell line POS [35]. The potential role of collagen in cell migration was further confirmed by experiments treating canine OSA cells with an inhibitor of P4AH1, a protein involved in collagen biosynthesis [77]. Inhibitor-treated HMPOS cells showed a higher dependency of cell migration on collagen synthesis under normal and hypoxic conditions, in comparison with the POS cell line. Song and collaborators also established that hypoxic conditions lead to upregulation of four proteins (P4HA1, PLOD1, PLOD2, and LOX) that are involved in collagen synthesis and a remodeling pathway in metastatic HMPOS [77]. Nevertheless, the strong limitation of both of the presented studies is that they were performed only on one metastatic OSA cell line (HMPOS).

\subsection{Ezrin and $p-E R M$}

Ezrin is a membrane-cytoskeleton linker that belongs to the ERM (ezrin/radixin/moesin) family. Ezrin plays a part in various biological processes, including cell adhesion and motility. The role of this protein is to link the plasma membrane to cytoplasmatic actin filaments [78]. This molecular connection enables an interaction between cells and their microenvironment and is proven necessary for metastasis [79]. Expression of ezrin has been identified in many human malignancies, with most significant aberrations in mesenchymal neoplasias [80]. Overexpression of this protein is associated with poor outcomes and a high propensity to metastasize. Jackson et al. [68] observed a correlation between higher ezrin mRNA expression and an invasive phenotype and found that expressing 
ezrin in non-invasive canine OSA cells enhanced their invasive potential. Ezrin is located in an inactive state in the cytoplasm. Phosphorylation of threonine and tyrosine at the C-terminus of the protein leads to conformational activation of its structure and enables a linkage between the C-terminus and actin cytoskeleton, as well as a connection between the N-terminus and cell membrane or its proteins [81].

Ezrin phosphorylation is regulated in a dynamic manner by protein kinase $\mathrm{C}$ (PKC) during metastatic progression in both human and canine OSA. To determine the involvement of PKC in the phosphorylation of ezrin in canine OSA, the WHA was performed on four patient-derived ezrin-expressing canine OSA cell lines treated with specific smallmolecule inhibitor of PKC [82]. Inhibition of PKC resulted in a noticeable decrease in cellular migration. The data suggest that PKC directed ezrin phosphorylation and the consequential migration of canine OSA cells [82]. An increased expression of ezrin and p-ERM was also demonstrated in vivo in HMPOS tumor tissue that metastasize to the lungs of mice 1 week after IT transplantation [83]. The expression of p-ERM decreased after 2 and 4 weeks. A non-metastatic cell line showed low or no expression of ezrin and p-ERM [83]. These results indicate a potential association between the expression of ezrin and p-ERM, the ability of canine OSA to metastasize, and an involvement of ezrin phosphorylation in early steps of the process [83]. In canine patients, a positive expression of ezrin and p-ERM was shown in $83 \%$ of spontaneous primary canine OSA samples [80]. Unfortunately, the study was performed only on primary OSA, not metastatic disease [81]. Dogs entered the study with no evidence of pulmonary metastasis on thoracic radiographs and no clinical evidence of metastasis to the other sides. However, the likely presence of micrometastasis can be assumed. The observed increase in ezrin and p-ERM in the primary tumor, combined with results from the study of Jaroensong et al. demonstrating [83] increased ezrin and p-ERM in the first week following IT tumor transplantation, may further support the idea that ezrin and p-ERM are involved early in the metastatic process. Early involvement may allow primary tumor cells to intravasate and transport to the lungs, after which p-ERM levels decrease as the metastatic tumor is established. Nevertheless, further investigations are required to evaluate the exact role of ezrin and p-ERM in the molecular mechanisms of canine OSA lung metastasis.

\subsection{Yes-Associated Protein (YAP) and Transcriptional Coactivator with PDZ-Binding Motif (TAZ)}

YAP and its paralog TAZ (also called WW domain-containing transcription regulator protein 1, WWTR1) are transcriptional coactivators that play a part in the transcription of genes implicated in cell proliferation and the suppression of apoptosis [84]. These proteins are expressed in almost every human solid tumor [85]. In the metastatic processes, YAP and TAZ facilitate cell migration, enhance cell survival in circulation and at secondary sites, and promote metabolic adaptation to the new environment [86]. TAZ and YAP mediate TGF $\beta$-induced carcinoma cell invasion and motility [87]. In metastatic canine OSA cell lines, TAZ depletion resulted in a significant decline in migratory ability, as opposed to non-metastatic primary tumor-derived cell lines [87]. Additionally, simultaneous TGF $\beta$ treatment lead to a noticeable reduction of migration only in the metastatic cell line, not in those of primary tumor origin [88]. The data suggest that the modulatory effect of YAP, TAZ, and TAZ-mediated TGF $\beta$ signaling on migration is cell line dependent. However, the impact of TAZ on the migration of metastatic-derived canine OSA cell lines is more distinct than the effect of YAP [88].

\subsection{The Tropomyosin-Related 00 A (TrkA)}

TrkA is a receptor that mediates differentiation, mitogenesis, and survival of neurons, through binding of neurothropin growth factors [89]. It is described that inhibition of TrKA signaling results in a reduction of proliferation and enhancement of apoptosis in murine and human immortalized osteoblast cell lines. Furthermore, the TrkA signaling pathway is believed to be involved in the proliferation and survival of canine OSA cells in both local and metastatic microenvironments [90]. Fan and collaborators [90] determined 
the positive membranous immunostaining of TrKA in most OSA cells in $66 \%(10 / 15)$ of primary bone lesions and in $75 \%(9 / 12)$ of spontaneously occurring canine OSA metastases, suggesting that TrKA serves as a potential therapeutic target of both primary and metastatic canine OSA [90].

\subsection{C-X-C Chemokine Receptor Type 4 (CXCR-4)}

CXCR-4 is associated with tissue-specific metastases in human malignancies, due to the high concentration of its endogenous ligand-CXCL12, including metastases to the lungs, bones, lymph nodes, and the liver [91]. Fan and collaborators [92] discovered high expression of CXCR-4 in canine osteosarcoma cell lines and in 2 of 10 canine OSA pulmonary metastases. In the same study, the authors assessed that ligation of CXCR4 with exogenous CXCL12 induced directional migration of canine OSA cells [92]. Byrum and collaborators [93] observed the impairment of directional migration of canine OSA cells after reduction of CXCR4 following zoledronate treatment [93]. This result is consistent with the previously described research [92] and may indicate that the CXCR-4 contribution in canine OSA directs migration as a part of the metastatic process [92,93]. Further studies of both in vitro and in vivo on more samples are needed to confirm this hypothesis.

\subsection{3. microRNA (miR-9 and miR-34a)}

Micro RNAs (miRNAs) are small single-stranded nucleic acids that regulate the expression of the protein-coding genes following transcription. Affecting genes in many molecular pathways, miRNAs regulate physiological processes significant to cell homeostasis [94]. It is well described that alterations of miRNA expression commonly occur in human neoplasias, and they can target genes involved in the genesis, progression, and metastasis of tumors [95]. In both human and canine OSA, aberrant expression of miRNA is associated with poor prognosis due to a higher risk of metastasis and decreased response to chemotherapy [96].

Fenger et al. [96] observed an upregulation of miR-9 in canine OSA cell lines and in primary OSA tumors, in comparison to normal canine osteoblasts. Canine OSA cells overexpressing miR-9 exhibited enhanced invasiveness and migration in comparison to control cells. Inhibition of miR-9 in canine OSA cells resulted in their reduced migration and invasion [97]. These findings support the presumption that miR-9 plays a role in the promotion of migration and invasion in canine OSA cells. One protein regulated by miR-9 that may promote the metastatic phenotype is gelsolin. Diminishment of gelsolin in several types of neoplastic cells resulted in a reduction of their motility [97].

Lopez et al. [98] reported decreased expression of miR-34a in canine OSA tumors and OSA cell lines in comparison to normal canine osteoblasts. OSA cells transduced with pre-miR-34a lentiviral vector show reduced invasion, cell motility, and scattering [98]. Lopez et al. [98] identified Kruppel-like factor 4 (KLF4), Semaphorin 3E (SEMA3E), and VEGFA in transduced and non-transduced OSA cells. These genes are associated with cell migration, and their transcripts are downregulated in cells with mi-R34a overexpression [98]. KLF4, SEMA3E, and VEGFA are presumed as miR-34a target genes, and the results imply that miR-34a may play a role in canine OSA metastasis by regulating their expression [98]. In further studies, Lopez and collaborators [97] showed a 50\% reduction of miR-34a expression in metastatic lesions in comparison to primary tumors. However, the limited number of the analyzed samples did not enable the establishment of strong conclusions about miR-34a expression and its role in metastases of canine OSA [98].

\subsection{Annexins}

Annexins are cellular proteins possessing the ability to dependently bind negatively charged phospholipids on calcium [99]. Annexins consist of two domains located on $\mathrm{COOH}$ and NH2 terminals, which are responsible for binding cell membrane phospholipids and cytoplasmic proteins, respectively. The major role of annexins is to provide a membrane scaffold for cells [100]. In humans, studies show a negative correlation between the 
expression of annexin 1 and the progression of breast carcinoma [101]. In canine OSA, Roy et al. [35] determined a significant decrease in annexin 1 production in the highly metastatic cell line HMPOS in comparison to the non-metastatic cell line POS. Conversely, the expression of annexin 2 is noticeably higher in the HMPOS cell line than in the POS cell line [35].

\subsection{Tissue Factor (TF)}

Tissue factor (TF) (also called thromboplastin or coagulation factor 3 ) is a transmembrane protein that initiates the conversion of prothrombin to thrombin in the coagulation cascade [102]. Through procoagulant and signaling activity, TF contributes to growth processes, angiogenesis, and metastasis in human malignancies, including colorectal carcinoma, breast carcinoma, melanocarcinoma, and glioblastoma [103]. Enhanced expression of this protein is correlated with shorter ST in human lung carcinoma [104]. In dogs, expression of TF is significantly higher in neoplasias of epithelial origin, such as pulmonary adenocarcinoma and mammary gland tumors, in comparison with mesenchymal malignancies like canine fibrosarcoma [105]. Stokol et al. [105] indicated a cell line-dependent expression of this protein in canine OSA. The authors noticed zero or minimal expression of TF in HMPOS and D17 cell lines, while in the OS2.4 cell line, the amount of TF resembled the expression in fibrosarcoma cells [105]. Differences in expression among particular cell lines can be associated with in vivo tumor behavior, a point Stokol and collaborators imply is indispensable for further investigations [105].

\section{Conclusions}

In Vitro and in vivo studies concerning canine OSA metastasis provide information on the specific biology and behavior of malignancies. Moreover, establishment of the specific factors involved in this process enables a broad understanding of its molecular mechanisms, effects on specific steps of the metastatic cascade, and may assist in the revelation of new therapeutic strategies in metastatic disease. Several proteins were examined for their role in the metastatic cascade of canine OSA (Table 1) in vitro or/and in vivo, using either induced animal models or a spontaneous canine model of the disease. The present review summarizes the results of up-to-date knowledge on genes and proteins potentially involved in canine OSA metastasis and points to further directions investigators should consider following to truly understand the molecular pathways involved in canine OSA metastasis. The strongest evidence evaluating both in vitro and in vivo studies presented for proteins involved a particular step of the metastasis cascade: EGFR for neoplastic cell migration; HGF-SF and Met-receptor for invasion; and $\Delta$ Np63, ezrin, p-ERM, Snail2, miR-9, and miR-34a for both migration and invasion. Further validation of in vitro results (on several metastatic cell lines) with in vivo methods (with a large enough sample size) is needed to portray all steps of the canine OSA metastatic process and to further develop novel therapeutic strategies. 
Table 1. Proteins and genes potentially involved in canine OSA metastasis evaluated with particular in vitro and/or in vivo methods.

\begin{tabular}{|c|c|c|c|c|c|}
\hline \multirow{2}{*}{ Protein/Gene } & \multicolumn{2}{|c|}{ In Vitro } & \multicolumn{2}{|c|}{ In Vivo } & \multirow{2}{*}{$\begin{array}{l}\text { Step(s) of the Metastatic } \\
\text { Cascade }\end{array}$} \\
\hline & Method & Cell Lines & Method & Samples & \\
\hline$p 63$ & $\begin{array}{c}\text { qRT-PCR; } \\
\text { WB; } \\
\text { TIA; } \\
\text { quantitative migration assay; } \\
\text { WHA [23] }\end{array}$ & Abrams, OSA8, OSA16, D17 [23] & necropsy and light microscopy [23] & SCID mice [23] & $\begin{array}{c}\text { invasion; } \\
\text { migration [23] }\end{array}$ \\
\hline Annexins & peptide fingerprinting [35] & HMPOS, POS [35] & - & - & $\begin{array}{c}\text { Invasion; migration } \\
{[106,107]}\end{array}$ \\
\hline CD147 & $\begin{array}{l}\text { peptide fingerprinting; } \\
\text { WB; } \\
\text { flow cytometry; } \\
\text { confocal microscopy; } \\
\text { IHC [35] }\end{array}$ & HMPOS, POS [35] & IHC [35] & $\begin{array}{l}\text { spontaneously occurring } \\
\text { canine osteosarcoma [35] }\end{array}$ & Invasion $[72,73]$ \\
\hline Collagen & $\begin{array}{c}\text { peptide fingerprinting [35]; } \\
\text { WHA [35,77]; nano-Lc-MS/MS } \\
\text { analysis, parallel reaction monitoring } \\
\text { (pRM) MS, WB [77] }\end{array}$ & HMPOS, POS $[35,77]$ & - & - & Migration [77] \\
\hline CXCR-4 & $\begin{array}{c}\text { directional migration assay }[92,93] \\
\text { RT-PCR; } \\
\text { WB; } \\
\text { flow cytometry; } \\
\text { IHC [92] }\end{array}$ & $\begin{array}{l}\text { POS, HMPOS, COS31, Buck, D17 } \\
\text { [92] K003 [93] }\end{array}$ & IHC [92] & $\begin{array}{l}\text { spontaneously occurring } \\
\text { canine osteosarcoma [92] }\end{array}$ & Migration $[92,93]$ \\
\hline EGFR & $\begin{array}{c}\text { WB; } \\
\text { IHC; } \\
\text { qRT-PCR [43] }\end{array}$ & $\begin{array}{l}\text { COS31, HMPOS, POS, D17, } \\
\text { KOS-001, KOS-002, KOS-003, } \\
\text { KOS-004 [43] }\end{array}$ & $\begin{array}{l}\text { tissue microarray; } \\
\text { IHC; } \\
\text { qRT-PCR [43] }\end{array}$ & $\begin{array}{l}\text { spontaneously occurring } \\
\text { canine osteosarcoma [43] }\end{array}$ & Migration [63] \\
\hline $\begin{array}{l}\text { Ezrin } \\
\text { p-ERM }\end{array}$ & $\begin{array}{l}\text { Matrigel IA } \\
\text { qRT-PCR; } \\
\text { WHA [82] }\end{array}$ & $\begin{array}{c}\text { MC-KOSA, SK-KOSA, BW-KOSA } \\
\text { [68] KOS-001, KOS-002, KOS-003, } \\
\text { KOS-004 [82] }\end{array}$ & $\begin{array}{c}\text { IHC; } \\
\text { necropsy; }[82,83]\end{array}$ & $\begin{array}{l}\text { SCID mice [82] BALB/c nude } \\
\text { mice [83] }\end{array}$ & invasion; migration [68] \\
\hline $\begin{array}{l}\text { HGF-SF } \\
\text { Met receptor }\end{array}$ & $\begin{array}{l}\text { Matrigel IA [58,60]; } \\
\text { Northern blot; } \\
\text { qRT-PCR [58]; }\end{array}$ & $\begin{array}{c}\text { D17 [58,60], D22 [60] Abrams, Grey } \\
{[58]}\end{array}$ & $\begin{array}{l}\text { Northern blot } \\
\text { analysis; } \\
\text { IHC [59] }\end{array}$ & $\begin{array}{l}\text { spontaneously occurring } \\
\text { canine osteosarcoma [59] }\end{array}$ & Invasion $[58,60]$ \\
\hline
\end{tabular}


Table 1. Cont.

\begin{tabular}{|c|c|c|c|c|c|}
\hline \multirow{2}{*}{ Protein/Gene } & \multicolumn{2}{|c|}{ In Vitro } & \multicolumn{2}{|c|}{ In Vivo } & \multirow{2}{*}{$\begin{array}{l}\text { Step(s) of the Metastatic } \\
\text { Cascade }\end{array}$} \\
\hline & Method & Cell Lines & Method & Samples & \\
\hline $\begin{array}{l}\text { IGF-1 } \\
\text { IGF1-R }\end{array}$ & $\begin{array}{c}\text { Matrigel IA; } \\
\text { WB; } \\
\text { qRT-PCR }[42,68], \text { Northern blot [42] }\end{array}$ & $\begin{array}{c}\text { Abrams, Grey, D17 [42], SK-KOSA, } \\
\text { MC-KOSA, BW-KOSA [68] }\end{array}$ & $\begin{array}{c}\text { Necropsy; } \\
\text { karyotypic analysis; [42] }\end{array}$ & athymic nude mice [42] & Invasion $[42,68]$ \\
\hline Integrins & $\begin{array}{l}\text { peptide fingerprinting [35]; } \\
\text { RT-PCR [68] }\end{array}$ & $\begin{array}{l}\text { HMPOS, POS [35], MC-KOSA, } \\
\text { SK-KOSA, BW-KOSA [68] }\end{array}$ & - & - & $\begin{array}{c}\text { invasion; migration } \\
{[66,68]}\end{array}$ \\
\hline $\begin{array}{l}\operatorname{miR}-9 \\
\operatorname{miR}-34 a\end{array}$ & $\begin{array}{c}\text { Matrigel IA; } \\
\text { WHA; } \\
\text { qRT-PCR; } \\
\text { Nano-LC/MS/MS; } \\
\text { [97,98], WB [97] }\end{array}$ & $\begin{array}{c}\text { OSA8, OSA16 [97,98], OSA2, } \\
\text { OSA40, OSA50, Abrams, D17 [98] }\end{array}$ & qRT-PCR [98] & $\begin{array}{l}\text { spontaneously occurring } \\
\text { canine osteosarcoma [97] }\end{array}$ & $\begin{array}{c}\text { invasion, migration } \\
{[97,98]}\end{array}$ \\
\hline Snail2 & $\begin{array}{l}\text { WHA [28]; } \\
\text { qRT-PCR [108] }\end{array}$ & D17 [28], OSCA-8 [108] & fluorescent microscopy [28] & the CAM model; [28] & $\begin{array}{c}\text { invasion, migration } \\
{[28,109], \text { intravasation }} \\
{[28]}\end{array}$ \\
\hline STAT3 & $\begin{array}{c}\text { WB; } \\
\text { RT-PCR; } \\
\text { gel zymography [21] }\end{array}$ & $\begin{array}{l}\text { OSA8, OSA11M, OSA16, OSA29, } \\
\text { OSA32, D17 [21] }\end{array}$ & - & - & Invasion [21] \\
\hline $\mathrm{TF}$ & $\begin{array}{c}\text { RT-PCR; } \\
\text { flow cytometry; } \\
\text { immunofluorescent microscopy [105] }\end{array}$ & HMPOS, D17, OS2.4 [105] & - & - & Invasion [110] \\
\hline TGF $\beta$ & WHA [53] & HMPOS, Abrams, D17 [53] & - & - & $\begin{array}{c}\text { Invasion, migration } \\
{[52,53]}\end{array}$ \\
\hline TrKA & - & - & IHC [90] & $\begin{array}{l}\text { spontaneously occurring } \\
\text { canine osteosarcoma [90] }\end{array}$ & $\begin{array}{l}\text { survival of the tumor cells } \\
\text { in metastatic tumor } \\
\text { microenvironment [11]] }\end{array}$ \\
\hline Vimentin & $\begin{array}{l}\text { peptide fingerprinting; } \\
\text { confocal microscopy; } \\
\text { WB [35] }\end{array}$ & HMPOS, POS [35] & - & - & invasion, migration [41] \\
\hline YAP and TAZ & migration transwell assay [88] & $\begin{array}{c}\text { D17, OVC-cOSA31, OVC-cOSA-75, } \\
\text { OVC-cOSA-78 [88] }\end{array}$ & - & - & $\begin{array}{l}\text { Migration }[85,88] \text {, } \\
\text { survival in circulation and } \\
\text { at the secondary sites [86] }\end{array}$ \\
\hline
\end{tabular}


Author Contributions: S.S.W. performed the literature search, prepared a table and figures, and wrote a major part of the manuscript. K.A.Z.-K. contributed to writing the manuscript, critically reviewed the manuscript for important intellectual content, and prepared the manuscript for publication. The manuscript is part of a Ph.D. thesis by S.S.W. All authors have read and agreed to the published version of the manuscript.

Funding: This research received no external funding.

Acknowledgments: The authors acknowledge Katarzyna Purzycka DVM, DipACVIM (Oncology) for providing Figure 1A and Jarosław Balcerzak DVM from the Kochanowskiego Veterinary Practice in Warsaw for providing Figure 1B,C.

Conflicts of Interest: The authors declare no conflict of interests related to this paper.

$\begin{array}{ll}\text { Abbreviations } \\ \text { CAM } & \text { chorioallantoic membrane } \\ \text { CID } & \text { Collision-induced dissociation } \\ \text { CMV } & \text { human cytomegalovirus } \\ \text { CT } & \text { computed tomography } \\ \text { DFI } & \text { disease-free interval } \\ \text { ECM } & \text { extracellular matrix } \\ \text { EGFR } & \text { epidermal growth factor receptor } \\ \text { EMMPRIN } & \text { extracellular matrix metalloproteinase inducer } \\ \text { EMT } & \text { epithelial-mesenchymal transition } \\ \text { ERM } & \text { ezrin/radixin/moesin } \\ \text { HGF-SF } & \text { hepatocyte growth factor-scatter factor } \\ \text { IA } & \text { (Matrigel) invasion assay } \\ \text { IGF-1 } & \text { insulin growth factor 1 } \\ \text { IGF1-R } & \text { insulin-like growth factor receptor 1 } \\ \text { IHC } & \text { immunohistochemistry } \\ \text { IL-8 } & \text { interleukin-8 } \\ \text { IL-11 } & \text { interleukin-11 } \\ \text { IT } & \text { intratibial } \\ \text { IV } & \text { intravenous } \\ \text { KLF4 } & \text { Kruppel-like factor 4 } \\ \text { MiRNA } & \text { micro RNA } \\ \text { MMPs } & \text { metalloproteinases } \\ \text { MRI } & \text { magnetic resonance imaging } \\ \text { mRNAs } & \text { messenger RNAs } \\ \text { MS } & \text { mass spectrometry } \\ \text { OSA } & \text { osteosarcoma } \\ \text { OSM } & \text { oncostatin M } \\ \text { p-ERM } & \text { phosphorylated ezrin-radixin-moesin } \\ \text { PKC } & \text { Protein Kinase C } \\ \text { qRT-PCR } & \text { quantitative Real Time PCR } \\ \text { rhHGF } & \text { recombinant human hepatocyte growth factor } \\ \text { SCID mice } & \text { severe combined immunodeficient mice } \\ \text { SEMA3E } & \text { Semaphorin 3E } \\ \text { SiRNA } & \text { silenced RNA } \\ \text { ST } & \text { survival time } \\ \text { STAT3 } & \text { signal transducer and activator of transcription 3 } \\ \text { TF } & \text { tissue factor } \\ \text { TGF } \beta & \text { transforming growth factor beta } \\ \text { TWI } & \text { transwell invasion } \\ \text { VEGF } & \text { vascular endothelial growth factor } \\ \text { VEGFA } & \text { vascular endothelial growth factor A } \\ \text { WB } & \text { Western blot } \\ \text { WHA } & \text { wound healing assay } \\ \text { YAP } & \text { yes-associated protein } \\ & \end{array}$




\section{References}

1. Cavalcanti, J.N.; Amstalden, E.M.I.; Guerra, J.L.; Magna, L.C. Osteosarcoma in dogs: Clinical-morphological study and prognostic correlation. Braz. J. Vet. Res. Anim. Sci. 2004, 41, 299-305. [CrossRef]

2. Dernell, W.S.; Straw, R.C.; Withrow, S.J. Tumors of the Skeletal System. In Small Animal Clinical Oncology; Withrow, S.J., MacEwen, E.G., Eds.; W.B. Saunders: Philadelphia, PA, USA, 2001; pp. 378-417.

3. Dobson, J.M.; Samuel, S.; Milstein, H.; Rogers, K.; Wood, J.L.N. Canine neoplasia in the UK: Estimates of incidence rates from a population of insured dogs. J. Small Anim. Pract. 2002, 43, 240-246. [CrossRef]

4. Egenvall, A.; Nødtvedt, A.; Euler, H. Von Bone tumors in a population of 400000 insured Swedish dogs up to 10 y of age: Incidence and survival. Can. J. Vet. Res. 2007, 71, 292-299.

5. Rowell, J.L.; McCarthy, D.O.; Alvarez, C.E. Dog models of naturally occurring cancer. Trends Mol. Med. 2011, 17, 380-388. [CrossRef] [PubMed]

6. Szewczyk, M.; Lechowski, R.; Zabielska, K. What do we know about canine osteosarcoma treatment?-Review. Vet. Res. Commun. 2015, 39, 61-67. [CrossRef] [PubMed]

7. Selvarajah, G.T.; Kirpensteijn, J. Prognostic and predictive biomarkers of canine osteosarcoma. Vet. J. 2010, 185, 28-35. [CrossRef] [PubMed]

8. Selmic, L.E.; Burton, J.H.; Thamm, D.H.; Withrow, S.J.; Lana, S.E. Comparison of carboplatin and doxorubicin-based chemotherapy protocols in 470 dogs after amputation for treatment of appendicular osteosarcoma. J. Vet. Intern. Med. 2014, 28, 554-563. [CrossRef] [PubMed]

9. Gebhard, C.; Miller, I.; Hummel, K.; Neschi née Ondrovics, M.; Schlosser, S.; Walter, I. Comparative proteome analysis of monolayer and spheroid culture of canine osteosarcoma cells. J. Proteom. 2018, 177, 124-136. [CrossRef]

10. Hapach, L.A.; Mosier, J.A.; Wang, W.; Reinhart-King, C.A. Engineered models to parse apart the metastatic cascade. Npj Precis. Oncol. 2019, 3. [CrossRef]

11. Anderson, R.L.; Balasas, T.; Callaghan, J.; Coombes, R.C.; Evans, J.; Hall, J.A.; Kinrade, S.; Jones, D.; Jones, P.S.; Jones, R.; et al. A framework for the development of effective anti-metastatic agents. Nat. Rev. Clin. Oncol. 2019, 16, 185-204. [CrossRef]

12. Marx, V. Models: Stretching the skills of cell lines and mice. Nat. Methods 2014, 11, 617-620. [CrossRef]

13. Solano, L.N.; Nelson, G.L.; Ronayne, C.T.; Jonnalagadda, S.; Jonnalagadda, S.K.; Kottke, K.; Chitren, R.; Johnson, J.L.; Pandey, M.K.; Jonnalagadda, S.C.; et al. Synthesis, in vitro, and in vivo evaluation of novel N-phenylindazolyl diarylureas as potential anti-cancer agents. Sci. Rep. 2020, 10, 1-10. [CrossRef]

14. Wesserling, M.; Drewa, T. Will In Vitro Tests Replace Animal Models in Experimental Oncology? J. Tissue Sci. Eng. 2011, 2, 2-5. [CrossRef]

15. Gengenbacher, N.; Singhal, M.; Augustin, H.G. Preclinical mouse solid tumour models: Status quo, challenges and perspectives. Nat. Rev. Cancer 2017, 17, 751-765. [CrossRef] [PubMed]

16. Chaffee, B.K.; Allen, M.J. A clinically relevant mouse model of canine osteosarcoma with spontaneous metastasis. In Vivo 2013, 27, 599-604.

17. Kim, Y.; Williams, K.C.; Gavin, C.T.; Jardine, E.; Chambers, A.F.; Leong, H.S. Quantification of cancer cell extravasation in vivo. Nat. Protoc. 2016, 11, 937-948. [CrossRef]

18. Onaciu, A.; Munteanu, R.; Munteanu, V.C.; Gulei, D.; Raduly, L.; Feder, R.I.; Pirlog, R.; Atanasov, A.G.; Korban, S.S.; Irimie, A.; et al. Spontaneous and Induced Animal Models for Cancer Research. Diagnostics 2020, 10, 660. [CrossRef]

19. Maniscalco, L.; Iussich, S.; Morello, E.; Martano, M.; Gattino, F.; Miretti, S.; Biolatti, B.; Accornero, P.; Martignani, E.; SánchezCéspedes, R.; et al. Increased expression of insulin-like growth factor-1 receptor is correlated with worse survival in canine appendicular osteosarcoma. Vet. J. 2015, 205, 272-280. [CrossRef] [PubMed]

20. Selvarajah, G.T.; Kirpensteijn, J.; van Wolferen, M.E.; Rao, N.A.S.; Fieten, H.; Mol, J.A. Gene expression profiling of canine osteosarcoma reveals genes associated with short and long survival times. Mol. Cancer 2009, 8, 72. [CrossRef] [PubMed]

21. Fossey, S.L.; Liao, A.T.; McCleese, J.K.; Bear, M.D.; Lin, J.; Li, P.K.; Kisseberth, W.C.; London, C.A. Characterization of STAT3 activation and expression in canine and human osteosarcoma. BMC Cancer 2009, 9, 1-15. [CrossRef]

22. Candi, E.; Dinsdale, D.; Rufini, A.; Salomoni, P.; Knight, R.A.; Mueller, M.; Krammer, P.H.; Melino, G. TAp63 and $\Delta$ Np63 in cancer and epidermal development. Cell Cycle 2007, 6, 274-284. [CrossRef]

23. Cam, M.; Gardner, H.L.; Roberts, R.D.; Fenger, J.M.; Guttridge, C.; London, C.A.; Cam, H. $\Delta$ Np63 mediates cellular survival and metastasis in canine osteosarcoma. Oncotarget 2016, 7, 48533-48546. [CrossRef]

24. Aggarwal, B.B.; Sethi, G.; Kwang, S.A.; Sandur, S.K.; Pandey, M.K.; Kunnumakkara, A.B.; Sung, B.; Ichikawa, H. Targeting signal-transducer-and-activator-of-transcription-3 for prevention and therapy of cancer: Modern target but ancient solution. Ann. N. Y. Acad. Sci. 2006, 1091, 151-169. [CrossRef] [PubMed]

25. Haura, E.B.; Turkson, J.; Jove, R. Mechanisms of disease: Insights into the emerging role of signal transducers and activators of transcription in cancer. Nat. Clin. Pract. Oncol. 2005, 2, 315-324. [CrossRef] [PubMed]

26. Nieto, M.A. The snail superfamily of zinc-finger transcription factors. Nat. Rev. Mol. Cell Biol. 2002, 3, 155-166. [CrossRef]

27. Sharili, A.S.; Allen, S.; Smith, K.; Hargreaves, J.; Price, J.; McGonnell, I. Expression of Snail2 in long bone osteosarcomas correlates with tumour malignancy. Tumor Biol. 2011, 32, 515-526. [CrossRef]

28. Sharili, A.S.; Allen, S.; Smith, K.; Price, J.; McGonnell, I.M. Snail2 promotes osteosarcoma cell motility through remodelling of the actin cytoskeleton and regulates tumor development. Cancer Lett. 2013, 333, 170-179. [CrossRef] [PubMed] 
29. Joseph, M.J.; Dangi-Garimella, S.; Shields, M.A.; Diamond, M.E.; Sun, L.; Koblinski, J.E.; Munshi, H.G. Slug is a downstream mediator of transforming growth factor- $\beta 1$-induced matrix metalloproteinase- 9 expression and invasion of oral cancer cells. $J$. Cell. Biochem. 2009, 108, 726-736. [CrossRef]

30. Zhang, K.; Chen, D.; Jiao, X.; Zhang, S.; Liu, X.; Cao, J.; Wu, L.; Wang, D. Slug enhances invasion ability of pancreatic cancer cells through upregulation of matrix metalloproteinase-9 and actin cytoskeleton remodeling. Lab. Investig. 2011, 91, 426-438. [CrossRef]

31. Verma, R.P.; Hansch, C. Matrix metalloproteinases (MMPs): Chemical-biological functions and (Q)SARs. Bioorg. Med. Chem. 2007, 15, 2223-2268. [CrossRef]

32. Lana, S.E.; Ogilvie, G.K.; Hansen, R.A.; Powers, B.E.; Dernell, W.S.; Withrow, S.J. Identification of matrix metalloproteinases in canine neoplastic tissue. Am. J. Vet. Res. 2000, 61, 111-114. [CrossRef]

33. Loukopoulos, P.; O’Brien, T.; Ghoddusi, M.; Mungall, B.A.; Robinson, W.F. Characterisation of three novel canine osteosarcoma cell lines producing high levels of matrix metalloproteinases. Res. Vet. Sci. 2004, 77, 131-141. [CrossRef]

34. Loukopoulos, P.; Mungall, B.A.; Straw, R.C.; Thornton, J.R.; Robinson, W.F. Matrix metalloproteinase-2 and -9 involvement in canine tumors. Vet. Pathol. 2003, 40, 382-394. [CrossRef] [PubMed]

35. Roy, J.; Wycislo, K.L.; Pondenis, H.; Fan, T.M.; Das, A. Comparative proteomic investigation of metastatic and non-metastatic osteosarcoma cells of human and canine origin. PLoS ONE 2017, 12, e0183930. [CrossRef] [PubMed]

36. Fuchs, E. Intermediate Filaments: Structure, Dynamics, Function, and Disease. Annu. Rev. Biochem. 1994, 63, 345-382. [CrossRef] [PubMed]

37. Levin, C.; Jørgensen, T.; Forsare, C.; Ola, P.; Anna, B.; Falck, K.; Fernö, M.; Lövgren, K.; Aaltonen, K.; Rydén, L. Expression of epithelial-Mesenchymal transition-Related markers and phenotypes during breast cancer progression. Breast Cancer Res. Treat. 2020. [CrossRef]

38. Li, C.; Balazsi, G. A landscape view on the interplay between EMT and cancer metastasis. Npj Syst. Biol. Appl. 2018, 4. [CrossRef] [PubMed]

39. Revenco, T.; Nicodème, A.; Pastushenko, I.; Sznurkowska, M.K.; Latil, M.; Sotiropoulou, P.A.; Dubois, C.; Moers, V.; Lemaire, S.; de Maertelaer, V.; et al. Context Dependency of Epithelial-to-Mesenchymal Transition for Metastasis. Cell Rep. 2019, 29, 1458-1468. [CrossRef]

40. Habel, N.; Stefanovska, B.; Carène, D.; Patiño-Garcia, A.; Lecanda, F.; Fromigué, O. CYR61 triggers osteosarcoma metastatic spreading via an IGF1R $\beta$-dependent EMT-like process. BMC Cancer 2019, 19, 1-18. [CrossRef]

41. Amaral, C.B.; da Silva Leite, J.; Fonseca, A.B.M.; Ferreira, A.M.R. Vimentin, osteocalcin and osteonectin expression in canine primary bone tumors: Diagnostic and prognostic implications. Mol. Biol. Rep. 2018, 45, 1289-1296. [CrossRef]

42. MacEwen, E.G.; Pastor, J.; Kutzke, J.; Tsan, R.; Kurzman, I.D.; Thamm, D.H.; Wilson, M.; Radinsky, R. IGF-1 receptor contributes to the malignant phenotype in human and canine osteosarcoma. J. Cell. Biochem. 2004, 92, 77-91. [CrossRef]

43. Selvarajah, G.T.; Verheije, M.H.; Kik, M.; Slob, A.; Rottier, P.J.M.; Mol, J.A.; Kirpensteijn, J. Expression of epidermal growth factor receptor in canine osteosarcoma: Association with clinicopathological parameters and prognosis. Vet. J. 2012, 193, 412-419. [CrossRef]

44. Gospodarowicz, D.; Abraham, J.A.; Schilling, J. Isolation and characterization of a vascular endothelial cell mitogen produced by pituitary-derived folliculo stellate cells. Proc. Natl. Acad. Sci. USA 1989, 86, 7311-7315. [CrossRef]

45. Henzel, W.J.; Ferrara, N. Pituitary follicular cells secrete a novel heparin-binding growth factor specific for vascular endothelial cells. Biochem. Biophys. Res. Commun. 1989, 161, 851-858.

46. Maeda, K.; Chung, Y.S.; Ogawa, Y.; Kang, S.M.; Ogawa, M.; Sawada, T.; Sowa, M. Prognostic Value of Vascular Endothelial Growth Factor Expression in Gastric Carcinoma. Cancer Interdiscip. Int. J. Am. Cancer Soc. 1996, 77, 858-863. [CrossRef]

47. Jinno, K.; Tanimizu, M.; Hyodo, I.; Nishikawa, Y.; Hosokawa, Y. Circulating vascular endothelial growth factor (VEGF) is a possible tumor marker for metastasis in human hepatocellular carcinoma. J. Gastroenterol. 1998, 33, 376-382. [CrossRef] [PubMed]

48. Kaya, M.; Wada, T.; Akatsuka, T.; Kawaguchi, S.; Nagoya, S.; Shindoh, M.; Higashino, F.; Mezawa, F.; Okada, F.; Ishii, S. Vascular endothelial growth factor expression in untreated osteosarcoma is predictive of pulmonary metastasis and poor prognosis. Clin. Cancer Res. 2000, 6, 572-577.

49. Pollak, M. Insulin and insulin-like growth factor signalling in neoplasia. Nat. Rev. Cancer 2008, 8, 915-928. [CrossRef]

50. Derynck, R.; Akhurst, R.J.; Balmain, A. TGF- $\beta$ signaling in tumor suppression and cancer progression. Nat. Genet. 2001, 29, 117-129. [CrossRef]

51. Wu, M.; Chen, G.; Li, Y. TGF- $\beta$ and BMP signaling in osteoblast, skeletal development, and bone formation, homeostasis and disease. Bone Res. 2016, 4, 16009. [CrossRef]

52. Li, S.; Li, F.; Cheng, T. TGF- $\beta 1$ promotes osteosarcoma cell migration and invasion through the miR-143-versican pathway. Cell Physiol. Biochem. 2014, 34, 2169-2179. [CrossRef]

53. Portela, R.F.; Fadl-Alla, B.A.; Pondenis, H.C.; Byrum, M.L.; Garrett, L.D.; Wycislo, K.L.; Borst, L.B.; Fan, T.M. Pro-tumorigenic effects of transforming growth factor beta 1 in canine osteosarcoma. J. Vet. Intern. Med. 2014, 28, 894-904. [CrossRef]

54. Galimi, F.; Brizzi, M.F.; Comoglio, P.M. The hepatocyte growth factor and its receptor. Stem Cells 1993, 11, 22-30. [CrossRef]

55. Sonnenberg, E.; Meyer, D.; Weidner, K.M.; Birchmeier, C. Scatter factor/hepatocyte growth factor and its receptor, the c-met tyrosine kinase, can mediate a signal exchange between mesenchyme and epithelia during mouse development. J. Cell Biol. 1993, 123, 223-235. [CrossRef] [PubMed] 
56. Bussolino, F.; Di Renzo, M.F.; Ziche, M.; Bocchietto, E.; Olivero, M.; Naldini, L.; Gaudino, G.; Tamagnone, L.; Coffer, A.; Comoglio, P.M. Hepatocyte growth factor is a potent angiogenic factor which stimulates endothelial cell motility and growth. J. Cell Biol. 1992, 119, 629-641. [CrossRef]

57. Grano, M.; Galimi, F.; Zambonin, G.; Colucci, S.; Cottone, E.; Zallone, A.Z.; Comoglio, P.M. Hepatocyte growth factor is a coupling factor for osteoclasts and osteoblasts in vitro. Proc. Natl. Acad. Sci. USA 1996, 93, 7644-7648. [CrossRef] [PubMed]

58. MacEwen, E.G.; Kutzke, J.; Carew, J.; Pastor, J.; Schmidt, J.A.; Tsan, R.; Thamm, D.H.; Radinsky, R. c-Met tyrosine kinase receptor expression and function in human and canine osteosarcoma cells. Clin. Exp. Metastasis 2003, 20, 421-430. [CrossRef] [PubMed]

59. Ferracini, R.; Angelini, P.; Cagliero, E.; Linari, A.; Martano, M.; Wunder, J.; Buracco, P. MET Oncogene Aberrant Expression in Canine Osteosarcoma. J. Bone Jt. Surg. Am. 2000, 82, 48. [CrossRef]

60. De Maria, R.; Miretti, S.; Iussich, S.; Olivero, M.; Morello, E.; Bertotti, A.; Christensen, J.G.; Biolatti, B.; Levine, R.A.; Buracco, P.; et al. Met Oncogene Activation Qualifies Spontaneous Canine Osteosarcoma as a Suitable Pre-Clinical Model of Human Osteosarcoma. J. Pathol. 2009, 218, 399-408. [CrossRef]

61. Oda, Y.; Naka, T.; Takeshita, M.; Iwamoto, Y.; Tsuneyoshi, M. Comparison of histological changes and changes in nm23 and c-MET expression between primary and metastatic sites in osteosarcoma: A clinicopathologic and immunohistochemical study. Hum. Pathol. 2000, 31, 709-716. [CrossRef] [PubMed]

62. Cohen, S.; Carpenter, G. Epidermal Growth Factor. Biochemistry 1990, 265, 7709-7712.

63. Wu, H.; Muscato, N.E.; Gonzalez, A.; Shyr, Y. An EGFR and AKT Signaling Pathway was Identified with Mediation Model in Osteosarcomas Clinical Study. Biomark. Insights 2007, 2. [CrossRef]

64. Wang, S.L.; Zhong, G.X.; Wang, X.W.; Yu, F.Q.; Weng, D.F.; Wang, X.X.; Lin, J.H. Prognostic significance of the expression of HER family members in primary osteosarcoma. Oncol. Lett. 2018, 16, 2185-2194. [CrossRef]

65. Giancotti, F.G.; Ruoslahti, E. Integrin Signaling. Science 1999, 285, 1028-1033. [CrossRef]

66. Stefanidakis, M.; Koivunen, E. Cell-surface association between matrix metalloproteinases and integrins: Role of the complexes in leukocyte migration and cancer progression. Blood 2006, 108, 1441-1450. [CrossRef] [PubMed]

67. Barroga, E.F.; Kadosawa, T.; Okumura, M.; Fujinaga, T. Establishment and Characterization of the Growth and Pulmonary Metastasis of a Highly Lung Metastasizing Cell Line from Canine Osteosarcoma in Nude Mice. J. Vet. Med. Sci. 1999, 61, 361-367. [CrossRef] [PubMed]

68. Jackson, M.; Serada, N.; Sheehan, M.; Srinivasan, S.; Mason, N.; Id, M.G.; Avadhani, N. Mitochondrial genome and functional defects in osteosarcoma are associated with their aggressive phenotype. PLoS ONE 2018, 13, e0209489. [CrossRef] [PubMed]

69. Yurchenko, V.; Constant, S.; Bukrinsky, M. Dealing with the family: CD147 interactions with cyclophilins. Immunology 2006, 117, 301-309. [CrossRef] [PubMed]

70. Saxena, D.K.; Oh-Oka, T.; Kadomatsu, K.; Muramatsu, T.; Toshimori, K. Behaviour of a sperm surface transmembrane glycoprotein basigin during epididymal maturation and its role in fertilization in mice. Reproduction 2002, 123, 435-444. [CrossRef]

71. Igakura, T.; Kadomatsu, K.; Taguchi, O.; Muramatsu, H.; Kaname, T.; Miyauchi, T.; Yamamura, K.I.; Arimura, K.; Muramatsu, T. Roles of basigin, a member of the immunoglobulin superfamily, in behavior as to an irritating odor, lymphocyte response, and blood-brain barrier. Biochem. Biophys. Res. Commun. 1996, 224, 33-36. [CrossRef] [PubMed]

72. Lu, Q.; Lv, G.; Kim, A.; Ha, J.M.; Kim, S. Expression and clinical significance of extracellular matrix metalloproteinase inducer, EMMPRIN/CD147, in human osteosarcoma. Oncol. Lett. 2012, 5, 201-207. [CrossRef] [PubMed]

73. Su, J.; Chen, X.; Kanekura, T. A CD147-targeting siRNA inhibits the proliferation, invasiveness, and VEGF production of human malignant melanoma cells by down-regulating glycolysis. Cancer Lett. 2009, 273, 140-147. [CrossRef] [PubMed]

74. Di Lullo, G.A.; Sweeney, S.M.; Körkkö, J.; Ala-Kokko, L.; San Antonio, J.D. Mapping the ligand-binding sites and diseaseassociated mutations on the most abundant protein in the human, type I collagen. J. Biol. Chem. 2002, 277, 4223-4231. [CrossRef]

75. Provenzano, P.P.; Inman, D.R.; Eliceiri, K.W.; Knittel, J.G.; Yan, L.; Rueden, C.T.; White, J.G.; Keely, P.J. Collagen density promotes mammary tumor initiation and progression. BMC Med. 2008, 6, 1-15. [CrossRef]

76. Elenjord, R.; Allen, J.B.; Johansen, H.T.; Kildalsen, H.; Svineng, G.; Mælandsmo, G.M.; Loennechen, T.; Winberg, J.O. Collagen i regulates matrix metalloproteinase-2 activation in osteosarcoma cells independent of S100A4. FEBS J. 2009, 276, 5275-5286. [CrossRef] [PubMed]

77. Song, Z.; Pearce, M.C.; Jiang, Y.; Yang, L.; Goodall, C.; Miranda, C.L.; Milovancev, M.; Bracha, S.; Kolluri, S.K.; Maier, C.S. Delineation of hypoxia-induced proteome shifts in osteosarcoma cells with different metastatic propensities. Sci. Rep. 2020, 10, 727. [CrossRef] [PubMed]

78. Fehon, R.G.; McClatchey, A.I.; Bretscher, A. Organizing the cell cortex: The role of ERM proteins. Nat. Rev. Mol. Cell Biol. 2010, 11, 276-287. [CrossRef]

79. Algrain, M.; Turunen, O.; Vaheri, A.; Louvard, D.; Arpin, M. Ezrin contains cytoskeleton and membrane binding domains accounting for its proposed role as a membrane-cytoskeletal linker. J. Cell Biol. 1993, 120, 129-140. [CrossRef]

80. Bruce, B.; Khanna, G.; Ren, L.; Landberg, G.; Jirström, K.; Powell, C.; Borczuk, A.; Keller, E.T.; Wojno, K.J.; Meltzer, P.; et al. Expression of the cytoskeleton linker protein ezrin in human cancers. Clin. Exp. Metastasis 2007, 24, 69-78. [CrossRef]

81. Khanna, C.; Wan, X.; Bose, S.; Cassaday, R.; Olomu, O.; Mendoza, A.; Yeung, C.; Gorlick, R.; Hewitt, S.M.; Helman, L.J. The membrane-cytoskeleton linker ezrin is necessary for osteosarcoma metastasis. Nat. Med. 2004, 10, 182-186. [CrossRef]

82. Hong, S.H.; Osborne, T.; Ren, L.; Briggs, J.; Mazcko, C.; Burkett, S.S.; Khanna, C. Protein kinase C regulates ezrin-radixin-moesin phosphorylation in canine osteosarcoma cells. Vet. Comp. Oncol. 2011, 9, 207-218. [CrossRef] [PubMed] 
83. Jaroensong, T.; Endo, Y.; Lee, S.J.; Kamida, A.; Mochizuki, M.; Nishimura, R.; Sasaki, N.; Nakagawa, T. Effects of transplantation sites on tumour growth, pulmonary metastasis and ezrin expression of canine osteosarcoma cell lines in nude mice. Vet. Comp. Oncol. 2012, 10, 274-282. [CrossRef] [PubMed]

84. Huang, J.; Wu, S.; Barrera, J.; Matthews, K.; Pan, D. The Hippo signaling pathway coordinately regulates cell proliferation and apoptosis by inactivating Yorkie, the Drosophila homolog of YAP. Cell 2005, 122, 421-434. [CrossRef] [PubMed]

85. Zanconato, F.; Cordenonsi, M.; Piccolo, S. YAP/TAZ at the Roots of Cancer. Cancer Cell 2016, 29, 783-803. [CrossRef]

86. Zanconato, F.; Cordenonsi, M.; Piccolo, S. YAP and TAZ: A signalling hub of the tumour microenvironment. Nat. Rev. Cancer 2019, 19, 454-464. [CrossRef]

87. Hiemer, S.E.; Szymaniak, A.D.; Varelas, X. The transcriptional regulators TAZ and YAP direct transforming growth factor $\beta$-induced tumorigenic phenotypes in breast cancer cells. J. Biol. Chem. 2014, 289, 13461-13474. [CrossRef]

88. Luu, A.K.; Schott, C.R.; Jones, R.; Poon, A.C.; Golding, B.; Hamed, R.; Deheshi, B.; Mutsaers, A.; Wood, G.A.; Viloria-Petit, A.M. An evaluation of TAZ and YAP crosstalk with TGF $\beta$ signalling in canine osteosarcoma suggests involvement of hippo signalling in disease progression. BMC Vet. Res. 2018, 14, 1-22. [CrossRef] [PubMed]

89. Reichardt, L.F. Neurotrophin-regulated signalling pathways. Philos. Trans. R. Soc. Lond. B Biol. Sci. 2006, 361, 1545-1564. [CrossRef]

90. Fan, T.M.; Barger, A.M.; Sprandel, I.T.; Fredrickson, R.L. Investigating TrkA expression in canine appendicular osteosarcoma. J. Vet. Intern. Med. 2008, 22, 1181-1188. [CrossRef]

91. Burger, J.A.; Kipps, T.J. CXCR4: A key receptor in the crosstalk between tumor cells and their microenvironment. Blood 2006, 107, 1761-1767. [CrossRef]

92. Fan, T.M.; Barger, A.M.; Fredrickson, R.L.; Fitzsimmons, D.; Garrett, L.D. Investigating CXCR4 expression in canine appendicular osteosarcoma. J. Vet. Intern. Med. 2008, 22, 602-608. [CrossRef] [PubMed]

93. Byrum, M.L.; Pondenis, H.C.; Fredrickson, R.L.; Wycislo, K.L.; Fan, T.M. Downregulation of CXCR4 Expression and Functionality After Zoledronate Exposure in Canine Osteosarcoma. J. Vet. Intern. Med. 2016, 1187-1196. [CrossRef]

94. Ambros, V. The functions of animal microRNAs. Nature 2004, 431, 350-355. [CrossRef]

95. Garzon, R.; Marcucci, G.; Croce, C.M. Targeting microRNAs in cancer: Rationale, strategies and challenges. Nat. Rev. Drug Discov. 2010, 9, 775-789. [CrossRef] [PubMed]

96. Sahabi, K.; Selvarajah, G.T.; Abdullah, R.; Kqueen Cheah, Y.; Chin Tan, G. Comparative aspects of microRNA expression in canine and human cancers. J. Vet. Sci. 2018, 19, 162-171. [CrossRef] [PubMed]

97. Fenger, J.M.; Roberts, R.D.; Iwenofu, O.H.; Bear, M.D.; Zhang, X.; Couto, J.I.; Modiano, J.F.; Kisseberth, W.C.; London, C.A. MiR-9 is overexpressed in spontaneous canine osteosarcoma and promotes a metastatic phenotype including invasion and migration in osteoblasts and osteosarcoma cell lines. BMC Cancer 2016, 16, 1-19. [CrossRef] [PubMed]

98. Lopez, C.M.; Yu, P.Y.; Zhang, X.; Yilmaz, A.S.; London, C.A.; Fenger, J.M. MiR-34a regulates the invasive capacity of canine osteosarcoma cell lines. PLoS ONE 2018, 13, e0190086. [CrossRef]

99. Ghoshdastider, U.; Popp, D.; Burtnick, L.D.; Robinson, R.C. The expanding superfamily of gelsolin homology domain proteins. Cytoskeleton 2013, 70, 775-795. [CrossRef] [PubMed]

100. Gerke, V.; Moss, S. Annexins: From structure to function. Physiol. Rev. 2002, 82, 331-371. [CrossRef] [PubMed]

101. Wang, L.; Bi, J.; Yao, C.; Xu, D.; Li, X.; Wang, S.; Li, L.; Zhang, D.; Wang, M.; Chang, G. Annexin A1 expression and its prognostic significance in human breast cancer. Neoplasma 2010, 57, 253-259. [CrossRef]

102. Bogdanov, V.Y.; Balasubramanian, V.; Hathcock, J.; Vele, O.; Lieb, M.; Nemerson, Y. Alternatively spliced human tissue factor: A circulating, soluble, thrombogenic protein. Nat. Med. 2003, 9, 458-462. [CrossRef]

103. Rak, J.; Milsom, C.; Yu, J. Tissue factor in cancer. Curr. Opin. Hematol. 2008, 15, 522-528. [CrossRef]

104. Regina, S.; Valentin, J.B.; Lachot, S.; Lemarié, E.; Rollin, J.; Gruel, Y. Increased tissue factor expression is associated with reduced survival in non-small cell lung cancer and with mutations of TP53 and PTEN. Clin. Chem. 2009, 55, 1834-1842. [CrossRef]

105. Stokol, T.; Daddona, J.L.; Mubayed, L.S.; Trimpert, J.; Kang, S. Evaluation of tissue factor expression in canine tumor cells. Am. J. Vet. Res. 2011, 72, 1097-1106. [CrossRef] [PubMed]

106. Kpetemey, M.; Dasgupta, S.; Rajendiran, S.; Das, S.; Gibbs, L.D.; Shetty, P.; Gryczynski, Z.; Vishwanatha, J.K. MIEN1, a novel interactor of Annexin A2, promotes tumor cell migration by enhancing AnxA2 cell surface expression. Mol. Cancer 2015, 14, 1-13. [CrossRef]

107. Zhao, C.; Zheng, S.; Yan, Z.; Deng, Z. CCL18 promotes the invasion and metastasis of breast cancer through Annexin A2. Oncol. Rep. 2020, 43, 571-580. [CrossRef] [PubMed]

108. Bulla, S.C.; Badial, P.R.; Silva, R.C.; Lunsford, K.; Bulla, C. Platelets Inhibit Migration of Canine Osteosarcoma Cells. J. Comp. Pathol. 2016, 1-11. [CrossRef] [PubMed]

109. Niinaka, Y.; Harada, K.; Fujimuro, M.; Oda, M.; Haga, A.; Hosoki, M.; Uzawa, N.; Arai, N.; Yamaguchi, S.; Yamashiro, M.; et al Silencing of autocrine motility factor induces mesenchymal to epithelial transition and suppression of osteosarcoma pulmonary metastasis. Cancer Res. 2010, 70, 9483-9493. [CrossRef]

110. Morris, D.R.; Ding, Y.; Ricks, T.K.; Gullapalli, A.; Wolfe, B.L.; Trejo, J. Protease-Activated Receptor-2 Is Essential for Factor VIIa and Xa-Induced Signaling, Migration, and Invasion of Breast Cancer Cells. Cancer Res. 2006, 66, 307-315. [CrossRef] [PubMed]

111. Astolfi, A.; Nanni, P.; Landuzzi, L.; Ricci, C.; Nicoletti, G.; Rossi, I. An anti-apoptotic role for NGF receptors in human rhabdomyosarcoma. Eur. J. Cancer 2001, 37, 1719-1725. [CrossRef] 